\title{
Slaying the crystal homunculus
}

The existence, or otherwise, of atoms was hotly debated for several centuries. In the early 1800s, Ellhardt Mitscherlich's descriptions of crystal structures enraged some, but struck a decisive blow for the 'atomist' cause.

\section{Robert W. Cahn}

$\square$ o atoms exist? And what makes a crystal? Early in the nineteenth century, soon after John Dalton announced his atomic hypothesis, these long-running and contentious issues in physical science became dramatically linked. It is often forgotten that the study of certain types of crystal was one of the key verifications of the atomic hypothesis.

The great French crystallographer RenéJust Haüy (1743-1822), for whom the taxonomy of mineral species was a life's work, believed that crystal forms were determined by molécules intégrantes, which he envisioned as tiny polyhedra. These were the smallest units into which a crystal could be broken down - the physical equivalent of the seventeenth-century view that a living embryo developed from a miniature 'homunculus' in the fertilized egg.

Haüy's crystal dogma overturned the much older theory of Kepler, Hooke and Huygens that one might explain the disposition of crystal faces in terms of the regular stacking of spherical atoms. Haüy convinced the world of mineralogy that crystals could not be understood in such terms, and that therefore there were no such entities as spherical atoms.

So it was not surprising that he attacked with sustained venom the astonishing findings of a German amateur mineralogist and professional chemist, Eilhardt Mitscherlich (1794-1863), who in 1818 found that the crystal forms of hydrated potassium phosphates and arsenates were identical. He went on to explore the same phenomenon among the sulphates and selenates. It is hard to appreciate today what a huge spanner this observation, of a phenomenon that came to be known as isomorphism, threw into the sedate machinery of nineteenth-century chemistry and mineralogy.

The young Mitscherlich took a long time to find his vocation. He began by studying oriental languages, before moving on to medicine and from there to chemistry, inspired by a Berlin chemistry professor, Heinrich Link, who was renowned as a man of wide interests. Both men were driven to find connections between apparently disparate themes, and Link urged his pupil on to the study that led to the recognition of isomorphism. To make a good job of it, Mitscherlich had to learn the techniques of mineralogy, and turned to an expert, Gustav Rose, for instruction.

Subsequently, Mitscherlich met the great Swedish chemist Jöns Berzelius (1779-1848), who took him under his wing and persuaded

NATURE |VOL 400 | 12 AUGUST 1999|www.nature.com

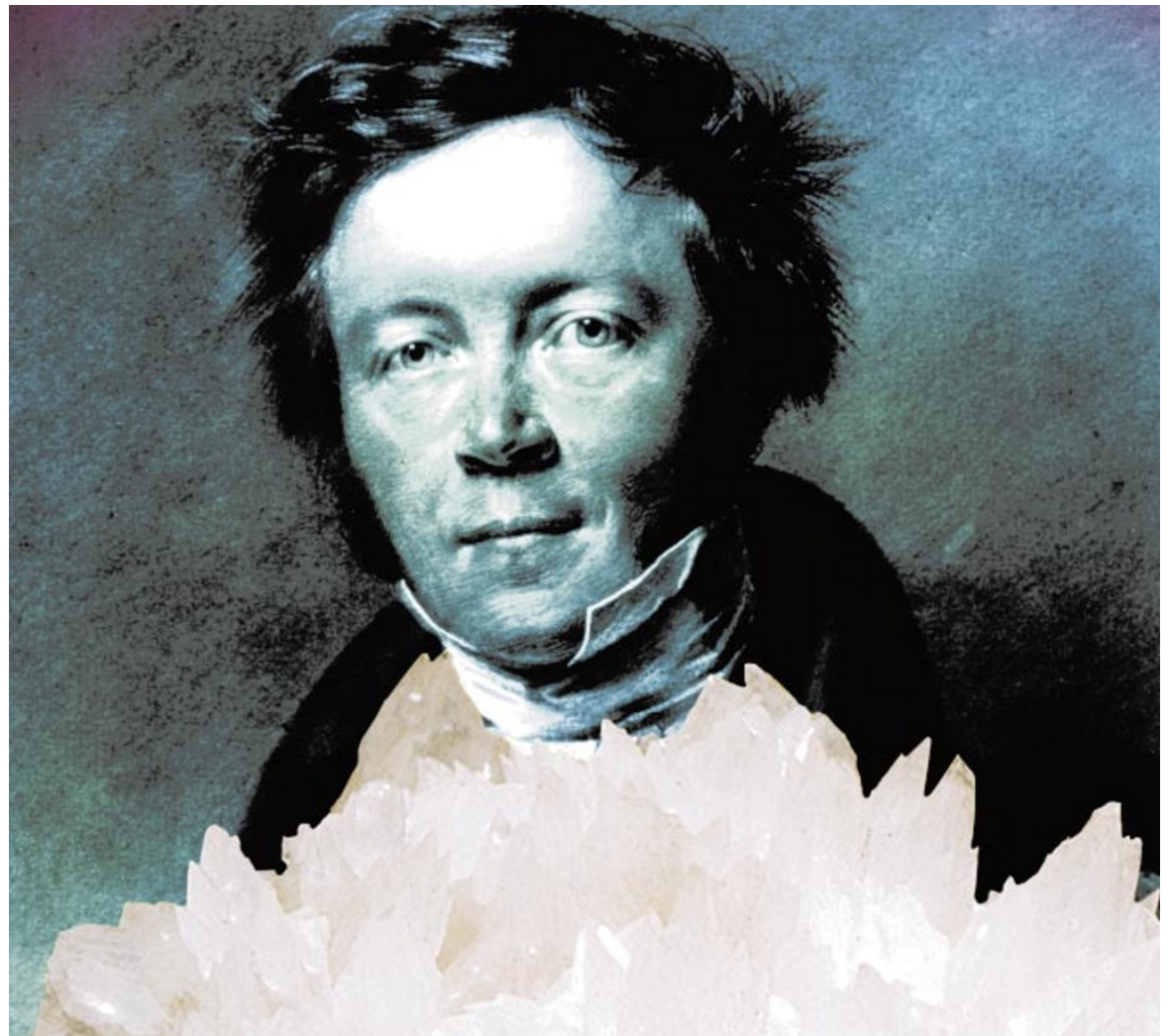

Mitscherlich: his discovery of isomorphism caused a stir in the sedate world of mineralogy.

the German authorities to appoint him, at a tender age, to a chair in Berlin. Mitscherlich's research on phosphates and arsenates was published more fully in 1821 in Swedish, and a German translation became a classic. There is an exact reprint of this translation, dated 1898, in the series Ostwald's Klassiker der Exakten Wissenschaften. (Wilhelm Ostwald was the father of physical chemistry, born a few years before Mitscherlich died.)

In the same 1821 paper, Mitscherlich also recognized the existence of polymorphs of the same substance, by reference to the classic puzzle of calcite and aragonite, both of which have the composition $\mathrm{CaCO}_{3}$. Later, he studied polymorphism and dimorphism - the existence of quite different crystal forms of the same substance - in sulphur. Haüy had twisted himself into knots trying to show that the two calcium carbonate polymorphs were not chemically identical, because polymorphism was incompatible with his model of the molécules intégrantes.

A third finding, made almost simultaneously with the discovery of isomorphism, by François Beudant in France and William Wollaston in England, was that isomorphous species can form a series of solid solutions with each other, what German miner- alogists came to name Mischkristalle, mixed crystals. This was also incompatible with the existence of molécules intégrantes.

Mitscherlich and Berzelius, respectful of Haüy as a great experimental scientist, tried for years to persuade him of the validity of their findings, but he was implacable. Berzelius finally declared that "one ought not to expect that a grey-haired scientist close to the end of an honourable life should give up a theory he erroneously considered to be the most important of his discoveries; this is perhaps too much to morally demand of any man".

Berzelius declared Mitscherlich's discovery and interpretation of isomorphism, jointly with Pierre-Louis Dulong and AlexisTherèse Petit's discovery in France that the specific heats of solids vary inversely with their (presumed) atomic weights, as the most important empirical proofs of the atomic hypothesis at that time. Yet there was widespread scepticism about atoms for another century, until Jean Perrin's work on Brownian motion early in the twentieth century finally routed the remaining disbelievers. Robert W. Cahn is in the Department of Materials Science and Metallurgy, University of Cambridge, Pembroke Street, Cambridge CB2 3QZ, UK. 